\title{
Community Participation in the Management of Sorong Nature Tourism Park, Sorong City
}

\author{
Yacob Fonataba ${ }^{1}$, Marlon I Aipassa ${ }^{1}$, B. D. A. S. Simarangkir ${ }^{1}$, Sumaryono ${ }^{1}$, Jacob Manusawai ${ }^{2}$, Vera F. \\ Manusawai $^{2} \&$ Anton S.Sinery ${ }^{2}$ \\ ${ }^{1}$ University of Mulawarman, Samarinda, Indonesia \\ ${ }^{2}$ Center of Environmental Research, University of Papua, Manokwari, Indonesia \\ Correspondence: Anton S. Sinery, Center of Environmental Research, University of Papua, Manokwari Indonesia. \\ Jl. Gunung Salju Amban Manokwari, Indonesia. Tel: 62-852-4430-8802. E-mail: anton_sineri@yahoo.com
}

\author{
Received: February 27, $2018 \quad$ Accepted: March 7, $2018 \quad$ Online Published: May 11, 2018 \\ doi:10.5539/eer.v8n1p48 URL: https://doi.org/10.5539/eer.v8n1p48
}

\begin{abstract}
This research aimed to identify the participation level of communities in the management program of Sorong Nature Tourism Park (NTP) and to provide alternative recommendations that can be used to support the success of the management program based on community participation. The results of the research showed that community participation in the management of Sorong NTP had the highest values in the household group (15 respondents or $40,54 \%$ ) and the lowest was group leader ( 1 respondent or $2,70 \%$ ), similar with the intensity of community participation. Community participation in Sorong NTP includes group leaders, interest group, head of household, women/housewives and youth. The participation level was categorized into very inactive and inactive, influenced by community participation function which generally occurred inthe form of implementing activity and intensity of participation of society element in the form of providing consultation and information. Management efforts include seeking legal aspects of the area to be the basis of management programs, seeking the payment of customary rights to ensure the existence of claims-related areas of the community, involving communities in planning, maintenance, management, decision-making, initiating action and control programs, and increasing the frequency of socialization and counseling to provide insight into the community about the economic means and the ecological meaning of the results of management program.
\end{abstract}

Keywords: participation, community, sorong, nature tourims park

\section{Introduction}

Sorong Nature Tourism Park (NTP) was issued based on the Minister of Agriculture Decree no. 397 / Kpts / Um / 5/1981 dated 7 May 1981 as a conservation area in Sorong City. It has an area of 945.9 hectares (BBKSDA West Papua, 2014). Here in after through Minister of Forestry Regulation Number P.02 / Menhut-II / 2007, the management authority was submitted from Sub-center of Protection and Nature Conservation (PNC) to Center for Natural Resources Conservation (BBKSDA) of Papua Barat.

Administratively Sorong Nature Tourism Park is situated in the District of East Sorong, Sorong City, Papua Barat Province. As the only remaining forest area in Sorong City, Sorong Nature Tourism Park plays an important role for the balance of the ecosystem of Sorong City, particularly in the provision of clean air, clean water and the fulfillment of natural recreation needs.

This area has high biodiversity of flora and fauna species. The wealth of flora is quite high and has economic value such as various types of medicinal herbs and orchids as well as various species of wildlife (Ponisri, 2012). According to the BBKSDA of Papua Barat (2014) Sorong Nature Tourism Park has 200 hectares of forest stands of plants (Agathis labilardieri, Podocarpus blumei, Araucaria cunninghamii and Eucalyptus deglupta), 57 species of woody plants (where some are consumed such as lanzones, jackfruit, durian, and mango), 28 species of orchids, 83 species of wildlife (13 species of mammals, 51 species of birds 16 species of reptiles, and 3 species of amphibians). There are11 species of wildlife which are protected and 6 species are endemic i.e. Paradiseae minorminor, Orioluszalayi, Melanocmaris nigra, Rhyticeruslicatus, eagle (Acipiterfasciatus, A. novaeholandeae) and frogs (Bufomelanotictus).

This area is geographically strategic in Sorong City since it has a very important role for the environment including 
the surrounding communities (Ponsiri, 2012). The surrounding communities have a high dependence on this forest both as a source of food, medicines, firewood, building materials and various ornamental plants that can be sold, especially orchids that have high marketvalue.

Since the management hand overfrom the Directorate General Forest Protection and Nature Conservation (FPNC) to the Center for Nature Resource Conservation of Papua Barat, various efforts have been conducted related to the protection, preservation and utilization of this forest, but the threat to the existence of this area continues. The existence of settlements, community gardens, the construction of road access for transportation of materials and the utilization of forest products indicate that the area is experiencing threats related to its function. According to Ponisri (2012), there are local villagers who are often fulfilling their needs within the area of Sorong Nature Toursm Park (NTP), namely the village ofKlablim and Klasaman. More over, according to Center for Natural Resources Conservation (BBKSDA) of Papua Barat (2011), there are some local villagers from several villages surrounding Sorong NTP who depend on this forest for their needs i.e. the village of Km14, Srahwata, and Kolamsusu. The existence of these villages is a potential threat to this NTP area if not managed properly. Therefore, management strategies need to be developed to ensure the use of the areas resources will be sustainable in the future.

Until now, reports or research on local community participation, especially in Sorong NTP have not been documented. Hence efforts to depict information about community participation in the region, such as the current study, are worthwhile. Such participation includes anyone who has been involvedin Sorong NTP management program so far, in terms of participating (function), the nature of the participation (intensity), how people's perceptions about participation and how management efforts can be developed to optimize management in the perspective of community participation. The purpose of this study was to determine the level of participation of local communities in Sorong NTP management program and to provide alternative strategies that can be used to support the successful management of Sorong NTP based on community participation. The results of the research can be used as input / referral for government and authorized institution in formulating policies related to management of Sorong Nature Tourism Park.

\section{Method}

\subsection{Site Selection}

The research was carried out in Sorong Nature Tourism Park which focused on Forest Farmer Group (the group of people who harvest fruit of Pometia acuminata) in the village of Klasaman, the sub-district of East Sorong, Sorong City, West Papua Province. Data collection took place over a four month period during February to May 2017.

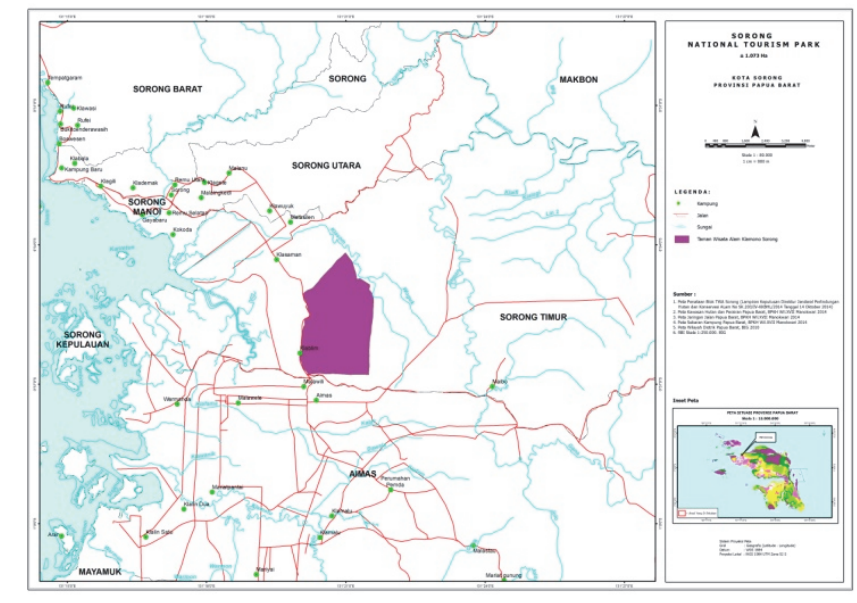

\subsection{Research Equipment and Material}

The tools utilizedfor this research consist of a digital camera, tape /voice recorder, writing tools (ballpoint, book, etc.) and computer. The camera was usedto document important objects in the field related to the scope of the research in order to facilitate the discussion, the tape recorder / HP was used to record the information during the interview to ensure accurate recording of respondent information, writing instruments such as calculators and computers for data processing and preparing research and questionnaire to obtain primary data from the respondents which are the main data to be analyzed.

\subsection{Research Data}


Data were collected in the form of primary data covering participating and non-participating elements of the community, community involvement in the function and intensity of participation, community perceptions about participation and issues related to Sorong NTP management. Furthermore, secondary data were in the form of general condition of the area obtained from local government (District Head, Village head, Forestry agency, Center for Natural Resources Conservation (BBKSDA) of Papua Barat and Regional Development Planning Agency of Sorong City) and other related institutions.

\subsection{Study Unit and Sampling Techniques}

The focal group of this research consisted of individuals from matoa farmers who reside in the village of Klasaman. The selection applied stratified sampling where population was divided into 5 strata in accordance with data processing formulation (Table 1).

Table 1. Respondents/interviewee on Community participation issues

\begin{tabular}{clc}
\hline No & \multicolumn{1}{c}{ Respondent } & Number of respondent interviewed \\
\hline $\mathbf{1}$ & Community leader & 1 \\
$\mathbf{2}$ & Forest farmer group & 4 \\
$\mathbf{3}$ & Village member (household) & 15 \\
$\mathbf{4}$ & Woman & 8 \\
$\mathbf{5}$ & Young people & 9 \\
\hline
\end{tabular}

Two types of data for this research were needed; primary and secondary data. Primary data were accumulated from direct observation, interviews and literature review (obtained from report, photos, press release). While secondary data were collected from local government (District Head, Village head, Forestry agency, Center for Natural Resources Conservation (BBKSDA) of Papua Barat, Regional Development Planning Agency of Sorong City) and other related institutions. These data were useful in providing background information to the study area and enriching the information that has been gathered during field observation and interviews.

\subsection{Data Analysis}

Data was analyzed simultaneously during data collection, in line with procedures used in qualitative research. The process of data analysis in qualitative research includes editing, coding, categorizing, calculating, tabulating and evaluating to build intervention and conclusion. Editing data was the activity of re-examining the data obtained. Coding was the activity of clarifying respondent source and respondent's answers according to category. The frequency was calculated after the coding has been done, both the respondent's source and the respondent's answer can be distributed into categories and frequency which can be calculated.

Assessing the level of local communities participation in the implementation of Sorong NTP management program, based on the multiplication of the index figures of actors, with the index figures in terms of what and the index figures on how participation (Table 1).

Table 2. Participation Index

\begin{tabular}{|c|c|c|}
\hline $\begin{array}{c}\text { Community } \\
\text { Elements }\end{array}$ & Function & Intencity \\
\hline 5. Youth & 5. Management & 5. Supervision \\
\hline 4. Woman & 4. Planning & 4. Organize initiative actions \\
\hline 3. & 3. & 3. Decision-making \\
\hline Housewife & Implementation & \\
\hline $\begin{array}{l}\text { 2. Interest } \\
\text { group }\end{array}$ & $\begin{array}{l}2 . \\
\text { Rehabilitation }\end{array}$ & 2. Providing consultation \\
\hline $\begin{array}{l}\text { 1. Local } \\
\text { leader }\end{array}$ & 1. Distribution & 1. Provide information \\
\hline
\end{tabular}


Source: Poli (1997) cited by Sinery dan Manusawai (2016)

Description: the numbers 1, 2, 3, 4, 5 are indexes.

The highest number is 5 , the lowest is 1.1 is the lowest score of participation rank and 5 is the highest score of the participation rank score with 5 groups of categories namelyvery inactive, inactive, active enough, active, and very active.

\section{Results and Discussion}

\subsection{Function of Community Participation}

Based on data obtained from Center for Natural Resources Conservation (BBKSDA) of Papua Barat, it was known that the management program carried out in the period of 2013 until now (May of 2017). There were 13 activities carried out, either programs conducted directly by Center for Natural Resources Conservation (BBKSDA) of Papua Barat and partners of BBKSDA. These activities have entirely involved people in the Sorong NTP area, including leaders, interest groups, household, groups of women and youth.

In general, the involvement of the community in the management of Sorong NTP on the participation function especially the participation of the community in the implementation of the management program by Center for Natural Resources Conservation (BBKSDA) of Papua Barat determined the motivation of the community for change. The changes were meant in terms of household economic changes and the demand to maintain the environmental quality as a consequence of development. This was a form of good collaboration in the implementation of the management program as it will foster experience and ownership. This will increase the sense of responsibility and willingness to defend the regionin the next stage of management. According to Levang et al. (2007), communities living in areas such as the PunanTribe who reside in the Sesayap catchment area in the Malinau District forest have a high dependence on forest potential, hence they will be implementing the natural resource management systems that have been conducted for years. According to Pattiselanoo (2006), Pattiselano and Koibur (2008), Pattiselano and Mentansan (2010), the interaction of the community with the region was seen by the utilization of natural resources in and around the forest area, which creates interdependence between the community and natural resources.

Table 3. Function of Forest farmer group in the management of Sorong Nature Tourism Park (NTP)

\begin{tabular}{clcc}
\hline No & Form of community participation & Number of Respondent & $\begin{array}{c}\text { Percentage } \\
\text { (\%) }\end{array}$ \\
\hline 1. & Management & 1 & 2,70 \\
2. & Planning & 3 & 8,11 \\
3. & Implementation & 14 & 37,84 \\
4. & Rehabilitation & 10 & 27,03 \\
5. & Distribution & 9 & 24,32 \\
Number of Respondent Participated & 37 & 100,00 \\
Number of Respondent not Participated & - & - \\
\multicolumn{2}{c}{ Amount } & 37 & 100,00 \\
\hline
\end{tabular}

Description:

1. Participation by providing information, consultation, decision-making, initiating action, implementation, maintenance, monitoring and evaluation.

2. Participation in program management, especially planning activities, especially the activities of preparing the village empowerment master plan.

3. Participation in the implementation of management activities of chicken farming programs and nurseries

4. Participation in supporting the success of programs, especially waste bank programs through the collection of plastic waste in the NTP area.

5. User of Sorong NTP management program specifically training activity including orchid silviculture, natural tourism guides, fire training, technical training of breeding, vegetative propagation training, agricultural 
training in polibag and interpreneur training of nature tour.

Table 3 shows that all respondents participated in the implementation of the program management of Sorong Nature Tourism Park which reveals the performance of the management is quite good in the implementation of the program. In addition, the background of the community was a group of forest farmers who were dependent on the implementation of programs conducted by Center for Natural Resources Conservation (BBKSDA) of Papua Barat and partners.

This condition was slightly different from the community participation in protected forest of Wosi Rendani the district of Manokwari which shows that the concentration of respondents was more identified in the function of distribution (use and implementation) (Sinery and Manusawai, 2016). However, the community participation function in Wosi Rendani protected forest does not include management functions and planning functions as identified in community participation in Sorong NTP. This was related to the condition of the community, a group of forest farmers so that the management of the program was more even and involving all members of farmer groups. Furthermore, program management was generally built from a joint planning to implementation and even to evaluation. According to Sallatang (1987) in the implementation phase of development projects there was relatively active participation of the community in various forms, such as attended the socialization, become object participants and took advantage of economic benefits. Usually the number of participating citizens was not enough. On the other hand, at the phase of planning and assessment generally community does not participate with the reason that they had been excluded.

\subsection{Intensity of Community Participation}

A detailed description of the quality of community participation in the management of Sorong NTP was illustrated through the intensity of community participation (Table 4).

Table 4. Intensity of participation of Forest farmer Group in the management Program of Sorong Nature Tourism Park

\begin{tabular}{llcc}
\hline No & Form of community participation & Number of Respondent & $\begin{array}{c}\text { Percentage } \\
\text { (\%) }\end{array}$ \\
\hline 1. Overall control & 4 & 10,81 \\
2. Initiate implementing action & 8 & 21,62 \\
3. Decision-making & 8 & 21,62 \\
4. Providing consultation & 7 & 18,92 \\
5 Providing information & 14 & 37,84 \\
Number of Respondent Participated & 37 & 100,00 \\
Number of Respondent not Participated & - & - \\
\multicolumn{2}{c}{ Amount } & 37 & 100,00 \\
\hline
\end{tabular}

Description:

1. Overall controlwas the participation of community elements in various forms of activities for the success of Sorong NTP management program.

2. Initiate action was the participation of community elements in the form of initiative actions for the implementation of Sorong NTPmanagement program

3. Decision-making was the participation of community elements in determining what should be done in the Sorong NTPmanagement program;

4. Providing consultation was the participation of community elements in solving the problems that arise with respect to the management program of Sorong NTP;

5. Providing information was the participation of community elements in the delivery of information both orally and in writing, on matters relating to SorongNTPmanagement program;

Community involvement in the management of Sorong Nature Tourism Park area was based on the intensity of participation including all forms of participation. Intensity of participation in the form of providing information 
was the highest form of participation at 14 respondents (37.84\%). Followed by initiating action and decision making, each with 8 respondents $(21,62 \%)$, and consultation as many as 7 respondents $(18,92 \%)$, while the lowest participation intensity is 4 respondents $(10.81 \%)$ in the form ofoverall control.

These conditions indicate that the form of community participation in the intensity of distributed participation was almost regularly distributed, despite differences in the form of overall control and providing information.

\subsection{Function and Intensity of Community Participation}

Function and intensity of community participation in the management of Sorong Nature Tourism park (Table 5).

Table 5. Participation Function and Intensity in the Management Program of Sorong NTP

\begin{tabular}{|c|c|c|c|c|c|c|}
\hline \multirow{2}{*}{ Form of participation } & \multicolumn{5}{|c|}{ Respondent } & \multirow[t]{2}{*}{ Amount } \\
\hline & Leaders & Interest group & Household & Woman & Youth & \\
\hline Management & - & 1 & - & - & - & 1 \\
\hline Planning & - & 3 & - & - & - & 3 \\
\hline Implementation & 1 & - & 6 & 7 & - & 14 \\
\hline Rehabilitation & - & - & 9 & 1 & - & 10 \\
\hline Distribution & - & - & - & - & 9 & 9 \\
\hline Total Amount & 1 & 4 & 15 & 8 & 9 & 37 \\
\hline Percentage (\%) & 2,70 & 10,81 & 40,54 & 21,62 & 24,32 & 100,0 \\
\hline Overall control & 1 & 2 & 1 & - & - & 4 \\
\hline Initiative action & - & 1 & 2 & 2 & 3 & 8 \\
\hline Decision Making & - & 1 & 5 & 2 & - & 8 \\
\hline Providing consultation & - & - & 1 & 3 & 3 & 7 \\
\hline Providing information & - & - & 6 & 1 & 3 & 10 \\
\hline Total Amount & 1 & 4 & 15 & 8 & 9 & 37 \\
\hline Percentage $(\%)$ & 2,70 & 10,81 & 40,54 & 21,62 & 24,32 & 100,0 \\
\hline
\end{tabular}

Community participation in the management of Sorong Nature Tourism Park was highest in the household group (15 respondents or $40.54 \%$ ) and the lowest was the leader group (1 respondent or $2.70 \%$ ). Similarly, the intensity of community participation, in which the element of household was the highest group with the number of respondents as many as 15 people or $40.54 \%$ and the lowest was the leader group ( 1 respondent or $2.70 \%$ ).

This illustrates that both the participation function and participation intensity of the household group were the highest participating groups in the management program of Sorong NTP.This shows normal conditions in the social stratification of the community. According to Sardjono (2004) household group, in this case the head of the household, was the first family member receiving innovation. After wards will be involved in the management of innovation. According to Sinery et al (2016); Sinery and Manusawai (2016), although there were differences in access to natural resources, the head of the household becomes the mainstay of the community in accepting an innovation / program / activity which was subsequently implemented. Furthermore, it was stated that this condition becomes the character of society that depend its life on natural resources.

\section{Participation Level of Community Elements}

The participation function of the community leader in the management of Sorong Nature Park was 1 respondent $(100 \%)$ in the form of implementation then the intensity of participation of community leader was 1 respondent $(100 \%)$ in the form of overall control. When tabulated in the Participation Empowerment Index table, the participation level of the community leader was equal to $1 \times 3 \times 5=15$ indicating that the participation of leaders in the management program of Nature Tourism Park Sorong was categorized as "very inactive" (in the values range of $1-25)$.

The participation function of interest group was 1 respondent $(25 \%)$ in the form of management and 3 respondents (75\%) in the form of planning. Furthermore, the participation intensity of interest group was 2 respondents (50\%) on the form overall control. When tabulated in the participation empowerment index table, the participation level 
of interest groups was equal to $2 \times 5 \times 5=50$, which indicates that the participation of the community of interest group elements was categorized as "inactive" (within the range of 26 - 50).

The participation function of the household (head) was as manyas 6 respondents $(40.0 \%)$ in the form of implementation, and 9 respondents $(60,0 \%)$ in maintenance form. Furthermore, the intensity of participation of household elements was 6 respondents (40.0\%) in the form of providing information and 5 respondents (33.33\%) in the form of decision-making. When stated in the table participation empowerment index, it is found that the participation level of the household head is $3 \times 3 \times 3=27$ and $3 \times 2 \times 1=6$, thus the participation of household group was categorized as "inactive" and "very inactive". Considering the range of the number of respondents by function and the intensity of participation (the largest number of respondents in the maintenance function), the level of community participation of the household head fitsinto the "very inactive" category (in the range of values $1-25)$.

The participation function of women group element was 7 respondents $(87,5 \%)$ in the form of "activity implementation", while the participation intensity counted for 3 respondents $(37,5 \%)$ in the form of providing consultation. If it was tabulated in the "participation empowerment index" table, the participation level of women group was $4 \times 3 \times 2=24$, therefore that the participation level of women group elements was categorized as "very inactive" (in the range of values $1-25$ ).

The participation function of youth element was found to be as manyas 9 respondents $(100 \%)$ in the form of distribution. Furthermore, the intensity of participation was 3 respondents $(33.33 \%)$ in the form of initiate action, 3 respondents $(33.33 \%)$ on providing consultation and 3 respondents $(33.33 \%)$ on providing information, consequently the participation rate of the youth element was $5 \times 1 \times 4=20$ or $5 \times 1 \times 2=10$ or $5 \times 1 \times 1=5$, indicating that the participation of youth groups falls into the category of "very inactive" (the value range of 1 25).

Participation levels include inactive and very inactive categories that demonstrate that low levels of public participation will impact on the failure of subsequent conservation programs. According to Margiono (1999), all elements of society should be actively involved in every process of development implementation because without the active involvement of society, the success and sustainability of development is impossible to achieve, can cause problems and even failure for development itself. According Sinery and Manusawai (2016) ideal conditions expected in collaborative management generally involve the participation of all elements of society both on planning, implementation and evaluation.

\section{Conclusion}

Community participation in Sorong nature tourism park includes group of community leader, interest group, head of household, housewife and youth. The participation level was categrorized into very inactive and inactive influenced by community participation function which generally occurred inthe form of implementing activity and participation intensity of society element, in the form of providing consultation and information.

\section{Acknowledgement}

The authors wishes local community in Sorong Nature Tourism Park, who assisted during field data collection. Special thanks is also extended to those who contributedto the research and writing of this article.

\section{References}

Balai Besar Konservasi Sumber Daya Alam Papua Barat. (2011). Rencana pembangunan jangka menengah taman wisata alam sorong periode 2012-2016 kota sorong provinsi papua barat.

Balai Besar Konservasi Sumber Daya Alam Papua Barat. (2014). Rencana pembangunan jangka pendek (2015) Taman Wisata Alam Sorong, Sorong Papua Barat.

Margiyono. (1999). Studi Tentang Partisipasi Masyarakat Lokal dalam Pembangunan Pedesaan. Program Pascasarjana Universitas Hasanuddin, Makasar.

Pattiselanno, F. (2006). The Wildlife Hunting in Papua.Biota, 11(1), 59-61.

Pattiselanno, F. (2007). Perburuan Kuskus (Phalangeridae) oleh Masyarakat Napan di Pulau Ratewi, Nabire Papua. Jurnal Biodiversitas, 8(4), 274-278.

Pattiselanno, F., \& Mentasan, G. (2010). Kearifan tradisional suku maybrat dalam perburuan satwa sebagai penunjang pelestarian satwa. Makara, Sosial Humaniora, 14(2), 75-82

Pattiselanno, F., \& Koibur, J. F. (2008). Cuscus (Phalangeridae) hunting by biak ethnic group in surrounding North Biak Utara Nature Reserve, Papua. Hayati Journal of Bioscience, (15), 130-134 
Ponisri (2012). Prospek konservasi jenis-jenis anggrek di taman wisata alam sorong papua barat. Tesis Program Pascasarjana Magister Program Studi Ilmu Kehutanan Universitas Mulawarman, Samarinda

Sallatang, M. A. (1987). Faktor-faktor yang menghambat partisipasi masyarakat dalam pembangunan di sulawesi tengah. Lembaga Penelitian Universitas Hasanuddin, Makasar.

Sardjono, M. A. (2004). Mosaik sosiologis kehutanan: masyarakat lokal, politik dan kelestarian sumberdaya. Debut Press, Jogyakarta

Sinery, A. (2015). Strategi pengelolaan kuskus di pulau numfor. Deepublish, Yogyakarta.

Sinery, A., Farida, W. R., \& Manusawai, J. (2016). The population of spotted cuscus (Spilocuscusmaculatus) and its habitat carrying capacity in Numfor Island, Papua, Indonesia. Biodiversitas, XVII(1), 315-321

Sinery, A. S., \& Manusawai, J. (2016). Community Participation of Management Program in The Wosi Rendani Protected Forest. Jurnal Manusia Dan Lingkungan, 23(3), 394-401

\section{Copyrights}

Copyright for this article is retained by the author(s), with first publication rights granted to the journal.

This is an open-access article distributed under the terms and conditions of the Creative Commons Attribution license (http://creativecommons.org/licenses/by/4.0/). 